\title{
Histological and Histomorphometric Analyses after Sinus Floor Augmentation with Different Grafting Materials
}

\author{
Marli de Lourdes Honorato Nakamura, ${ }^{1}$ Eduardo Eidi Nakamura, ${ }^{1}$ MonalisaMoreira da Silva Ribeiro, ${ }^{2}$ Marianne \\ Spalding, ${ }^{3}$ Claudemir de Carvalho, ${ }^{4}$ Sandra Irene Sprogis dos Santos, ${ }^{2}$ Luís Otávio Palhari ${ }^{* *}$ \\ ${ }^{1}$ Specialist in Implantology-Lato Sensu Postgraduate Program, FUNVIC University Center, Brazil \\ ${ }^{2}$ Dentistry professor, FUNVIC University Center, Brazil \\ ${ }^{3}$ Environmental Engineering Department, São Paulo State University (UNESP), Brazil \\ ${ }^{4}$ Dean of Research, Centro Universitário FUNVIC-UniFUNVIC, Brazil \\ ${ }^{5}$ Rector. Professor in the Lato Sensu Postgraduate Program, FUNVIC University Center, Brazil
}

\begin{abstract}
Homogeneous grafts from a bone bank, heterogeneous grafts and allow plastic grafts have already been studied and used for maxillary sinus elevation in order to reconstruct the bone for placement of dental implants. The present work aims to histologically assess bone neoformation from autogenous and heterogeneous (or xenogenous) bone grafts, in maxillary sinus lift surgery, an invasive technique. Six patients (total of 10 elevated maxillary sinuses) participated in the study with an alveolar bone remnant in the posterior region of the maxilla, less than $5 \mathrm{~mm}$, classification by Misch SA-4, evidenced through panoramic radiography. After a waiting period of tissue repair of 8 months, samples were collected and microscopic analysis was performed in 3 groups: autogenous group, Bio-Oss ${ }^{\circledR}$ group and Endobon ${ }^{\circledR}$ group. It was observed that the autogenous group has a statistically higher amount of bone matrix when compared to the other 2 groups. These did not differ from each other. The three types of grafts used promoted the expected new bone formation. Thus, one can choose any of the grafts evaluated to enable the installation of Osseointegrated implants and prosthetic rehabilitation in patients with the atrophic posterior maxilla.
\end{abstract}

Keywords: Bone graft, Lifting of the maxillary sinus, Biomaterials, Osseointegration

\section{Introduction}

The maxillary sinus is the widest of the paranasal cavities and occupies the entire body of the jaw. It resembles a quadrangular pyramid, whose base is located on the lateral nasal wall, communicating with the nasal cavity through the orifice called ostium. ${ }^{1}$ Its apex is extended towards the zygomatic process. It is the only one present and radiographically identified at birth. Usually around 18 years of age it reaches definitive shape and size. ${ }^{2}$
The surgery to elevate the maxillary sinus floor, introduced by Tatum $^{3}$ contributed greatly to the recovery of the bone structure of the posterior maxilla, lost due to tooth absences, with the purpose of rehabilitating itself through implants, patients who were previously called "oral invalid". The objective of the surgery is to create a space between the membrane and the floor of the maxillary sinus that will be filled with a graft material, capable of allowing bone neoformation and osseointegration of an osseointegrated implant immediately or later. ${ }^{4,5}$

\begin{tabular}{l|l}
\hline \hline Quick Response Code: & FCorresponding author: Luís Otávio Palhari. Reitoria. Estrada Radialista Perci Lacerda, 1000 \\
CEP.12412-825 Pindamonhangaba-SP, Brazil \\
Received: 20 September 20, 2021 \\
Citation: Nakamura MLH, Nakamura EE, Ribeiro MMS, Spalding M, Carvalho C, et al. Histolog- \\
ical and Histomorphometric Analyses after Sinus Floor Augmentation with Different Grafting \\
Materials. SOJ Den Oral Disor. 2021;1(4):1-8. DOI: 10.53902/SOJDOD.2021.01.000516
\end{tabular}


A considerable amount of materials has been used as filling material in the lifting of the floor of the maxillary sinus. These materials can be classified according to some criteria, such as origin (autogenous, homogeneous, heterogeneous and synthetic), biological reaction (biotolerated, bioinert and bioactive), physical characteristics (inorganic, demineralized and fresh) and according to biological properties (osteoconductive, osteoinductive, osteogenic, osteopromotor and osteostimulator). ${ }^{6,7}$ Various materials, such as homogeneous grafts from a bone bank, heterogeneous grafts (such as lyophilized bone) and alloplastic grafts (such as hydroxyapatite) have already been studied and used. However, it is known that no other material presents results as predictable as fresh autogenous bone, since the cell transplant and the BMP (morphogenetic protein) contained in the graft characterizes it as the gold standard in alveolar bone reconstructions. ${ }^{8}$

Autogenous bone has the particularity of offering osteopromotion due to its osteogenic, osteoconductive and osteoinductive capacities, characteristics not found in other grafting material classes. ${ }^{8}$ As a result, bone formation is considerably faster than when using only bone substitutes. However, its collection is performed during the surgical procedure, which increases the time and morbidity. It is important to note that the osteogenic potential of auto grafts can vary considerably with age, presence or absence of systemic diseases, donor area (iliac jaw or crest, cortical or spongy bone) and bone tissue collection technique (crusher, scraper or sucker with filter), which will result in bone fragments with different sizes). ${ }^{9}$ Different materials for grafting produce bone, which is visible on histological examination. The use of a bone that is not autogenous has been recommended due to the lower morbidity for the patient. Graft and new bone remodel in response to functional load. ${ }^{10}$

The recommended period for graft consolidation, prior to the placement of osseointegrated implants, is 6 to 8 months. However, when more than $5 \mathrm{~mm}$ of bone height is available and the bone allows good stability of the osseointegrated implant, osseointegrated implants can be placed simultaneously with the graft, which does not increase the treatment time. ${ }^{11}$ Autogenous bone needs less time (4 to 6 months) for bone neoformation than other biomaterials, which normally need 7 to 12 months. ${ }^{12}$ Adequate bone formation from 5 to 6 months can be achieved with a variety of materials, as long as a reasonable healing period is allowed, with no clinical evidence of the superiority of autogenous bone over other bone substitutes. When autogenous bone is used separately as a graft material, a bone fraction is found in a shorter healing period, 3 to 4 months, justified by its osteogenic potential. ${ }^{13}$

It is important to note that both bone quality and quantity are fundamental factors for treatment. The smaller particles of autogenous bone graft are also rapidly reabsorbed, with simultaneous greater bone apposition than when larger particles are used. The small size of the particles increases the surface of contact with the tissue that surrounds them. ${ }^{14}$ Currently, xenografts, especially of bovine origin, have been used more in humans, due to their easy availability, availability and similarity. ${ }^{15}$ Products derived from bovine bone have excellent biocompatibility, being an abundant and highly safe source of material. The treatment processes to which they are submitted (deproteinization, demineralization and lyophilization) reduce the risk of antigenicity or zoonoses. ${ }^{16}$

Maximo and Wassal ${ }^{17}$ evaluated grafts of autogenous bone and bovine bone (Bio-Oss $\AA$ ) in bicortical bone defects of rat calvaria. After 15 and 30 days after surgery, the amount of bone quantified in the group that received autogenous bone was significantly higher. There was no complete repair of the defects in either group. Despite the group that received autogenous bone to have presented a greater amount of bone tissue, after 30 days. However, bovine bone has the advantage of availability and reduced surgical time.

Kaufman ${ }^{18}$ reports that the lifting of the maxillary sinus simultaneously with the installation of osseointegrated implants dispenses with the second surgical stage, resulting in a reduction in treatment time. In view of the above, the objective of this work was to histologically assess bone neoformation from autogenous and xenogenous bone grafts, in maxillary sinus lift surgeries to reconstruct bone bed, for placing dental implants after a waiting period for tissue repair of 8 months.

\section{Materials and Methods \\ Characterization of patients}

Six patients of both sexes, with an average age of 47 years (ranging from 32 to 62 years) were selected. Patients were evaluated for the presence of systemic disease such as hypertension, diabetes mellitus and heart disease and for the presence of periodontal diseases. Harmful habits such as smoking and drinking alcoholic beverages were also avaliated Table 1.

\section{Surgical procedures}

This research followed the precepts of ethics and was previously approved by the Research Ethics Committee of the Faculty of Pindamonhangaba, according to protocol no $183 / 2012$. Ten elevations of the sinus membrane were performed, with 3 maxillary sinuses filled with autogenous bone (donor area, mandible retromolar trigone); 3 maxillary sinuses with xenogenous bone filling, BioOss ${ }^{\circledR}$, Geistlich Pharma AG; 4 maxillary sinuses with xenogenous bone filling, Endobon $\AA$, Biomet $3 i^{19}$ As pre- and postoperative medication, it were used: Amoxicillin 500mg-1box, orally, 1capsule every 8 hours for 7 days, started 24 hours before the procedure; Naproxen 500mg-1box, orally, 1 tablet every 12 hours for 5 days, started 12 hours before the procedure; Ibuprofen $400 \mathrm{mg}-1$ box, orally, 1 tablet every 6 hours, while in pain, started 1 hour before surgery; $0.12 \%$ chlorhexidine (Noplack or Periogard), topical use, $1 / 2$ cap every 12 hours, started 7 days after surgery. 
Table 1: Characterization of patients by gender, age, habits and health condition.

\begin{tabular}{|c|c|c|c|c|c|}
\hline Patients & Sex/Age & Smoking & Drinking & Systemic disease & Periodontal disease \\
\hline 1 & F, 32y & No & No & No & No \\
\hline 2 & F, 43y & No & No & No & No \\
\hline 3 & F, 55y & No & No & No & No \\
\hline 4 & M, 39y & No & No & No & No \\
\hline 5 & M, 51y & Yes & No & No & No \\
\hline 6 & M, $62 y$ & No & No & No & N \\
\hline
\end{tabular}

The surgical procedure was performed using the invasive maxillary sinus technique (modified Caldwell-Luc technique). After intraoral asepsis with a $0.12 \%$ chlorhexidine and extraoral rinse with polvidine, patients were anesthetized and an incision was made with a No. 15C scalpel blade in the gum, inserted in the ridge crest, accompanied by a mesial relaxant. and distal, followed by a mucoperiosteal to superior divulsion exposing the buccal bone wall of the maxilla. After the delimitation of the maxillary sinus, an osteotomy of the sinus lateral wall was performed, using a No.6 diamond spherical drill and a 1:1 angular piece with a rotation of 25,000 rpm and irrigation with $0.9 \%$ sterile sodium chloride solution until the appearance of the sinus membrane.

Using curettes suitable for this technique, the membrane was fully released and raised, creating a space that was filled with biomaterial. In cases where the sinus membrane was perforated accidentally, a collagen membrane was adapted over the perforated sinus membrane, protecting the site, and continuing with the surgery. Then, the mucoperiosteal tissue was repositioned and sutured with a non-resorbable suture thread. The patient received postoperative instructions and after two weeks the stitches were removed. After the bone repair period, a new panoramic radiograph was performed.

Eight months after surgery, samples from the region were collected for quantitative and qualitative evaluation of the newly formed bone, using trephine drills, with an internal diameter of $2.0 \mathrm{~mm}$. Two to three samples were collected, two samples for small maxillary sinuses and three samples for large maxillary sinuses.

\section{Histological and histomorphometric analysis}

The samples were fixed in $10 \%$ buffered formalin, then they were demineralized in EDTA solution (ethylenediamine tetra-acetic acid dihydrated disodium salt-Titriplex III?p.a-Merck-KgaA, Darmstadt, Germany) and sodium hydroxide P.A. (Merck-KgaA, Darnstadt, Germany). The fragments were processed and prepared for paraffin inclusion in the Histology Laboratory of the Institute of Science and Technology-ICT of the Universidade Estadual Paulista, "Júlio de Mesquita Filho", UNESP, São José dos Campos, SP. Semi-serial cuts of $5 \mu \mathrm{m}$ thickness were made, stained with hematoxylin and eosin (HE) and Mallory for analysis under optical microscopy.
The double-blind study method was used as a criterion for validating experimental practices, both for descriptive and quantitative analyzes.

For the descriptive analysis, the original magnifications of $100 \mathrm{x}$ and 400x were used, which allowed a detailed analysis of the connective tissue that permeated the bone trabeculae, their cellularity, the presence of mononuclear inflammatory infiltrate, the existence of grafted material and its appearance, as well as its relation with connective tissue and bone trabeculae.

To perform the histomorphometric analysis on the bone, planimetry by counting points was performed, using a quadrangular standard lattice composed of 154 points resulting from the intersections between vertical (14) and horizontal (11) lines Figure $1 \&$ Figure 2 . The reticulum was superimposed on microscopic images, captured in a Zeiss Axiophot 2 binocular light microscope (Carl Zeiss, Oberköchen, Germany) with a 10x eyepiece and objective The images were obtained by an Axio Cam MRc5 (Zeiss) digital camera, attached to the microscope and evaluated on the monitor with the Axio Vision Rel 4.7.2 software (Zeiss). Histomorphometric analysis was performed with the aid of the National Institute of Health (NIH) computer program Image-J Windows version, in the public domain. The relationship between the number of points on the bone structure and the total number of points in the reticulum corresponded to the proportion of the area of the structure analyzed. The intersection points that were located on the bone matrix were considered. ${ }^{20}$

\section{Statistical analysis}

The results were submitted to descriptive (mean, median and standard deviation) and inferential statistics: analysis of variance test (ANOVA) and Tukey's multiple comparison tests. The level of significance was set at $\mathrm{p}<0.05$.

\section{Results}

All fragments belonging to the same groups exhibited very similar microscopic characteristics. According to the results of the descriptive analysis, it was observed that in the fragments submitted to autogenous graft, the bone tissue exhibited a normal aspect, with viable osteocytes and large osteoblasts permeating the bone 
matrix. The medullary spaces were predominantly filled with loose connective tissue, rich in cells and with numerous blood vessels Figure 1.

In fragments submitted to graft with Endobon ${ }^{\circledR}$, thinner bone trabeculae were observed, permeated by amorphous basophilic material, sometimes with a dense aspect, sometimes loose. The other areas exhibit loose connective tissue, with bulky fibroblasts and focal areas of mononuclear inflammatory infiltrate. Birefringent granular particles can be observed dispersed or grouped throughout the sample Figure 2. All fragments that received the graft with Bio-Oss $®$ also exhibited very similar characteristics. Areas of viable bone trabeculae and bone fragments devoid of osteocytes, compatible with graft material, were observed. The connective tissue was more fibrous, although with a lot of cells, showing the inductive effect of the grafted material. Normal bone tissue was sometimes in close contact with the graft material Figure 3.

According to the proposed methodology, ahistomorphometric analysis was performed to quantify the bone matrix. There was difference in relation to the amount of bone matrix between

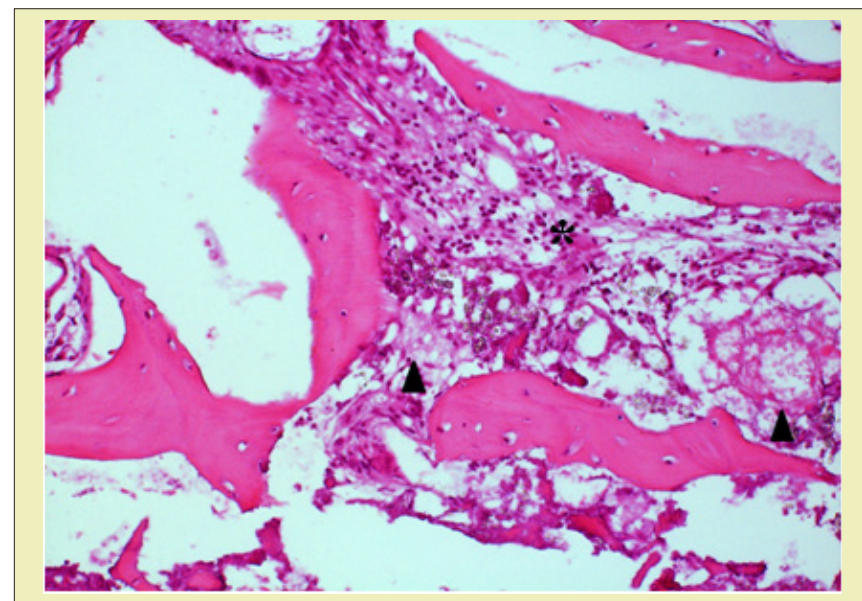

Figure 2: Photomicrograph of thin bony trabeculae permeated by amorphous material $(\boldsymbol{\Delta})$ and areas of mononuclear inflammatory infiltrate ${ }^{*}$ ) in biopsies of bone fragments submitted graft with Endobon®. Original magnification 100x.HE. the groups analyzed. The Autogenous group showed a statistically higher amount of bone matrix $(62.44 \pm 6.12)$ compared to the Endobon $\AA(36.25 \pm 11.33)$ and Bio-Oss $\AA$ groups $(33.89 \pm 8.72)$. Figure 4 illustrates the results obtained.

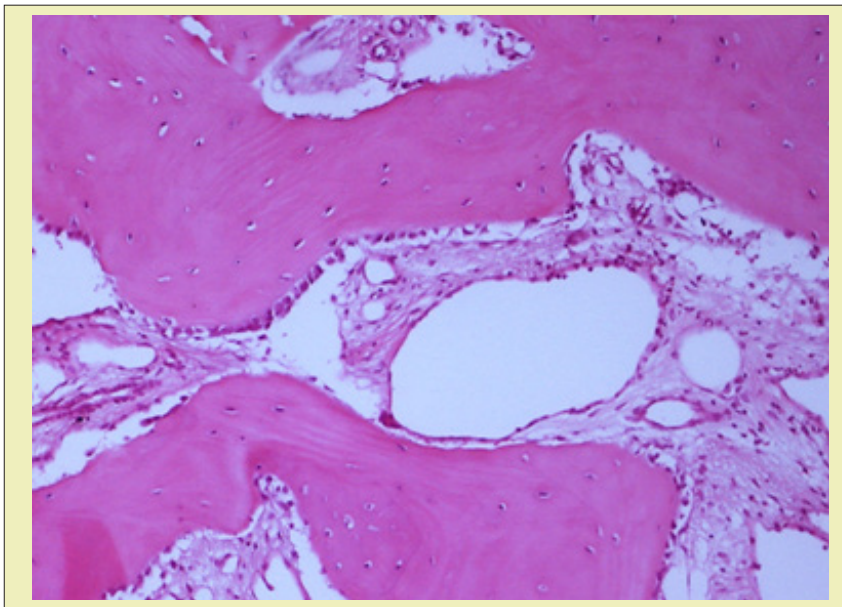

Figure 1: Normality aspect of an autogenous graft fragment. Original magnification 200x. HE.

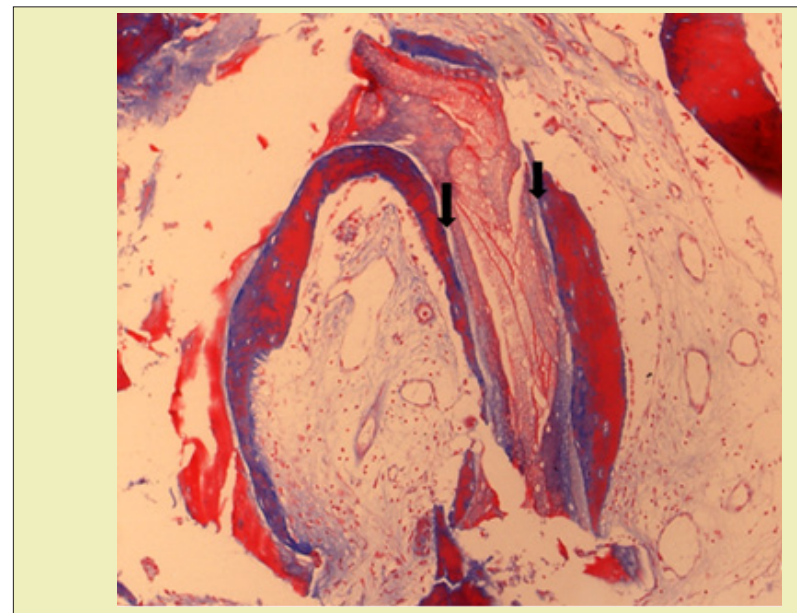

Figure 3: Photomicrograph of a bone fragment in which a graft with Bio-Oss $\AA$ was placed. Observe the intimate contact between the trabeculae of bone tissue with the graft material (arrows). Original magnification 100x. Mallory.

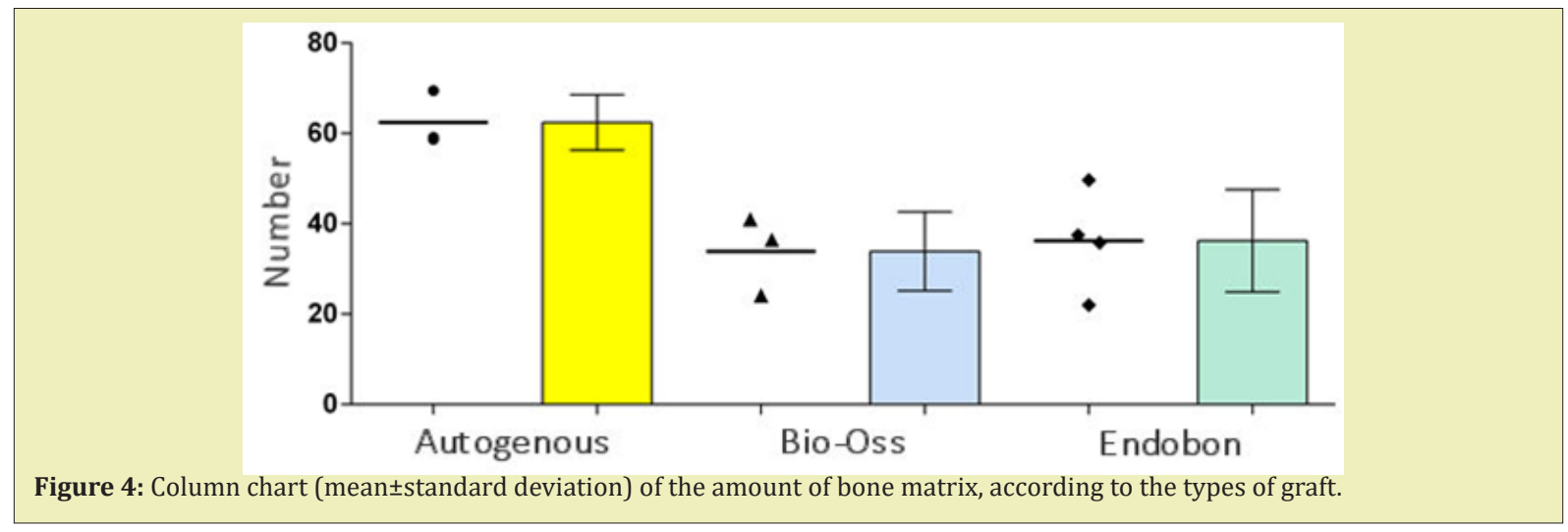


Patients were evaluated for smoking and drinking habits and for the presence of systemic and periodontal diseases. Only one patient claimed to be a smoker and none of them reported having a systemic disease. In the clinical analysis, none of them showed to have periodontal disease, so there was no influence of these characteristics on the results. The age and sex of the patients did not influence the results either.

\section{Discussion}

Maxillary sinus lift surgery has a relatively predictable result with a favorable success rate, being the technique of choice for cases of rehabilitation of the posterior region of the maxilla where bone height is limited by the pneumatization of the maxillary sinus and resorption of the alveolar crest. ${ }^{21}$ The materials used to fill the maxillary sinus elevations can be: autogenous, homogeneous or allograft, heterogeneous or xenogenous and synthetic or alloplastic. ${ }^{15,22}$ The use of materials other than autogenous bone has been recommended due to reducing morbidity for the patient.

Xenografts, especially of bovine origin, are the most used today. They present excellent biocompatibility, being an abundant and highly safe source of material. ${ }^{17,23}$ Bio-Oss $®$, preferably combined with autogenous bone particles, is a suitable material for elevating the maxillary sinus in a severely atrophic maxilla. ${ }^{24}$ The intimate contact between the graft material and the newly formed bone observed in histological studies confirm the osteoconductive properties of the. ${ }^{25-27}$

Several authors have investigated lyophilized bovine bone grafts and have shown positive results, sometimes related to bone neoformation, sometimes related to the maintenance of bone mineral density, and/or vertical height of the bone crest. ${ }^{25-30}$

Maiorana et al. ${ }^{29}$ performed a clinical study in 10patients with edentulous posterior maxilla who underwent maxillary sinus enlargement using the 2-stage technique and the placement of osseointegrated implants. After elevating the sinus mucosa, the cavities were filled with a 1: 1 mixture of cancellous bone and bovine lyophilized bone (Bio-Oss®). Samples for histological evaluation were collected before implantation, 5 to 7 months after grafting. The results showed that Bio-Oss $®$ is a reliable osteoconductive material and its association with spongy bone leads to new bone formation with increased density.

The data obtained by Sartoriet al. ${ }^{28}$ agree with the above works. The authors quantitatively evaluated ossification after the use of Bio-Oss $®$ in an increase in the maxillary sinus, after 8 months, 2 and 10 years after surgery. A bone neoformation of $29.8 \%(70.2 \%$ Bio-Oss ()$\pm 2.6$ was observed in 20 sections of the specimen \pm 2.6 after 8 months. At 2 years, bone tissue increased to $69.7 \% \pm 2.7$ and 10 years was $86.7 \% \pm 2.8$. According to the histomorphometric findings, it was noted that over time there was a significant increase in bone formation and, also, the reabsorption of the Bio-Oss $®$ particles.

The biomaterial Endobon $₫$ was biocompatible, osteoconductive and non-resorbable when used to repair of a bovine lyophilized bone graft in the tibia of rabbits, showing that it is a possible bone substitute as it does not alter the bone repair process. ${ }^{25}$

Ramírez-Fernándezet al. ${ }^{30}$ compared grafts of Endobon ${ }^{\circledR}$ (bovine lyophilized bone) and Osteo Biol $\AA$ mp3 (pig lyophilized bone) in the tibia of rabbits, through radiographic and histomorphometric analysis. Although the best results were obtained with the Osteo Biol ${ }^{\circledR}$ mp3 graft, both materials are biocompatible and osteoconductive, and can be considered bone substitutes. In the present study, in the descriptive analysis, both Bio-Oss $₫$ and Endobon $\AA$ showed similar results, but an inflammatory infiltrate was observed around Endobon $\AA$, and a larger area of viable bone trabeculae in the group that received Bio-Oss $®$, showing its slight superiority.

The aforementioned studies are in agreement with the results of this study and indicate that bovine xenograft is a material that can be used to fill in elevations of maxillary sinuses showing satisfactory results. Travassos et l. $^{26}$ reported a case of an edentulous patient with tomographic evidence of bilateral residual bone height less than $5 \mathrm{~mm}$ in the posterior region of the maxilla. The patient underwent surgery for maxillary sinus elevation using lyophilized inorganic bovine bone (Bio-Oss $®$ ) in the right sinus and hydroxyapatite associated with beta tricalcium phosphate $(\mathrm{HA}+\beta$ TCP, BoneCeramic) in the left. A new computed tomography scan was performed 8 months after the grafting procedure and it was demonstrated a gain in height of mineralized tissue, enabling the installation of osseointegrated implants. When installing the implants, samples were obtained from the areas for histological analysis, in which the remaining biomaterials were found, surrounded by newly formed bone tissue and loose connective tissue. In the group that received Bio-Oss $\AA$, it was noted that the areas of mineralized material were more evident. It was concluded that both materials were able to promote bone height gain, showing similar clinical and tomographic behaviour after 8 months.

Corroborating the results of Travassos et al., ${ }^{26}$ Corá et al. ${ }^{27}$ reported a case of bilateral maxillary sinus elevation in a 49-year-old patient, using Bio-Oss $\AA$ and Bone Ceramic, separately. In the histological sections, an intimate contact was observed between the biomaterial and the newly formed bone tissue, however, bone tissue surrounding the Bio-Oss $®$ particles, and the greater amount of inflammatory cells around Bone Ceramic were more noticeable. The authors confirmed the osteoconductive properties of the investigated biomaterials and concluded, based on the results that BioOss $®$ is slightly superior, but studies involving a larger number of patients are still needed. 
Our data are similar to those of Corá et al., ${ }^{27}$ since when comparing the histological aspects of Bio-Oss $\AA$ and Endobon $\AA$, we verified a larger area of viable bone trabeculae in the group that received Bio-Oss $\AA$, showing its slight superiority.

Due to the characteristics of autogenous osteo conduction and osteo induction bone, it has been used as a graft. ${ }^{31}$

Raghoebar et al. $^{32}$ evaluated the technique of lifting the maxillary sinus floor with autogenous grafts in 43 patients who did not have enough maxillary alveolar crest for the safe placement of osseointegrated implants. They used grafts from the iliac crest, mandibular symphysis or maxillary tuberosity. The authors concluded that lifting the maxillary sinus with an autogenous bone graft is a safe procedure for placing osseointegrated implants. The same was concluded by Vasconcelos et al. ${ }^{33}$ with the placement of implants in the upper posterior region of a 44-year-old patient after an enlarged maxillary sinus with an autogenous graft from the retromolar region.

The autogenous bone graft and the installation of the osseointegrated implant can be performed in 1 stage, when there is a bone height of at least $5 \mathrm{~mm}$ between the floor of the maxillary sinus and the crest of the ridge and 6 to $7 \mathrm{~mm}$ buccal-lingual diameter. If the remaining bone is not sufficient to stabilize the osseointegrated implant, surgery in 2stages is recommended, with the graft being performed first and, subsequently, the osseointegrated implants. ${ }^{32}$ One of the advantages of autogenous bone as a graft material is its angiogenic potential, stimulating the rapid growth of vessels from the remaining bone. This revitalizes parts of the graft and its cells, which will subsequently participate in local metabolism, that is, osteoclastic reabsorption and functional remodelling guided by osteoblasts. ${ }^{34}$

Jang et al. ${ }^{31}$ observed that, generally, in the maxillary sinus lifting technique, graft resorption and replacement start with cells acting from the peripheral area of the graft. An adequate elevation of the maxillary sinus must include the elevation of the medial wall membrane, providing blood support to the graft, originating from the sinus bone walls, allowing a faster formation of vital bone and the reduced time required for graft maturation. The graft volume is usually proportional to the size of the maxillary sinus, thus, the time required for graft resorption and replacement by the new bone is greater in larger sinuses. Thus, the high osteogenic potential of autogenous bone is essential when maxillary sinus lifting is performed on large maxillary sinuses.

Jang et al. ${ }^{31}$ agree with Artzi et al. ${ }^{35}$ who stated that if the graft is not in contact with the medial wall, the osseoconductive effect cannot contribute to the formation of new bone. It can be expected that in narrower maxillary sinuses the use of materials with only osseoconductive potential offers better results, whereas, in larger maxillary sinuses, the use of autogenous bone is indicated by its osteogenic properties. In our study, histological sections showed that autogenous bone showed superior results in relation to xenogenous bone. The bone tissue showed a normal aspect, with viable osteocytes and large osteoblasts permeating the bone matrix. The medullary spaces were predominantly filled with loose connective tissue, well acellularized and with numerous blood vessels, confirming the osteogenic properties and the angiogenic potential of the autogenous graft.

The use of autogenous bone of extraoral origin increases costs and morbidity for the patient, so donor sites in the intraoral region are also used. If the amount of donor bone is small or limited as in the intraoral area, the use of association with bone substitutes is recommended to minimize morbidity and the necessary time, as well as injuries and exposures of nerves or vessels, without losing the osteogenic properties of the autogenous bone. ${ }^{35,36}$ Others prefer the use of bone substitutes only, as they consider a second surgical site (donor area) uncomfortable to the patient ${ }^{31}$ Jang et al. ${ }^{31}$ and Crespi et al..$^{36}$ observed that it does not matter the origin of the autogenous bone, but the amount of cortical bone of the graft, which can imply a faster or slower resorption of it, that is, cortical bone behaves like cortical bone, regardless of its origin.

Hallman et $a .^{37}$ evaluated clinically and histologically the integration of titanium implants in different graft materials, for maxillary sinus elevation. Particulate autogenous bone from the mandibular branch, bovine lyophilized bone (Bio-Oss $₫$ ) with the use of a membrane, or a mixture of 80/20 autogenous bone and bovine lyophilized bone in 36 maxillary sinuses of 21 patients were used. The waiting time for the grafts was 6 to 9 months. In the histomorphometric analysis there was no difference between the three groups, indicating that the autogenous bone graft can be replaced by lyophilized bovine bone at $80 \%$ or $100 \%$, when used to elevate the maxillary sinus. The effect of adding autogenous bone remains uncertain, but it may allow for a reduction in waiting time.

John and Wenz ${ }^{38}$ evaluated the use of natural mineral bone, BioOss® alone or in combination with autogenous bone in elevations of the maxillary sinus, in 1 or 2 surgical stages. In all 38 patients there was a significant increase in neo formed bone and a reduction in biomaterial particles. There was no significant difference in the amount of bone neoformation between the Bio-Oss $®$ group and the autogenous bone+Bio-Oss® group. They also observed that bone neoformation occurred within 8 months after surgery. The association with autogenous bone may allow a reduction in waiting time. ${ }^{31}$ Jang et al. ${ }^{31}$ and Gutwald et al. ${ }^{34}$ report that the proportion of autogenous graft and other graft material depends on the amount of autogenous bone available. A higher proportion of autogenous bone increases the osteogenic potential in the mixture. 
Some authors recommend a waiting time for bone repair of 6 to 8 months. ${ }^{11}$ Others report a waiting time of 2 to 10 months, depending on the bone remaining in the maxillary sinus. ${ }^{28,39,40}$ For our study, a waiting period of 8 months was recommended, regardless of the biomaterial used. Histological sections showed that the group that received the Endobon ${ }^{\circledR}$ graft presented thin bone trabeculae, permeated by an amorphous material, sometimes dense and sometimes loose, in addition to lose connective tissue with bulky fibroblasts and inflammatory infiltrate, containing birefringent granules. In the Bio-Oss $®$ graft group, the characteristics were similar, with areas of viable bone trabeculae and bone fragments devoid of osteocytes, compatible with graft material and more fibrous connective tissue, highly cellularized, showing the inducing effect of the grafted materials. . Histomorphometric analysis showed that there was an increase in bone formation due to the greater amount of bone matrix when compared to the Bio-Oss ${ }^{\circledR}$ and Endobon $₫$ groups, suggesting that the autogenous bone graft was more efficient in stimulating bone neoformation corroborating results obtained by Coubetet al.. ${ }^{41}$

However, the histological aspects of the other groups together with data from the literature allows us to affirm the bone of bovine origin can be used as filling material in maxillary sinus surgeries by the invasive technique. However, further studies are needed to assess the behavior of these biomaterials in bone repair and longterm maintenance.

\section{Conclusion}

In the evaluated patients, the three types of grafts used promoted the expected new bone formation. Despite the small number of patients, these results, reinforced by those presented in the literature, show that one can choose any of the grafts evaluated to enable the installation of osseointegrated implants and prosthetic rehabilitation.

\section{Acknowledgments}

None.

\section{Funding}

None.

\section{Conflicts of interest}

Author declares that there is no conflict of interest.

\section{References}

1. Whyte A, Boeddinghaus R. Correction to The maxillary sinus: physiology, development and imaging anatomy. Dentomaxillofac Radiol. 2019;48:20190205c.

2. Mavrodi A, Paraskevas G. Evolution of the paranasal sinuses'anatomy through the ages. Anat Cell Biol. 2013;46(4):235-238.

3. Tatum OH. Maxillary and sinus implant reconstruction. Dent Clin North Am. 1986;30(2):207-229.
4. Yildirim M, Spiekrmann H, Biesterfeld S, et al. Maxillary sinus augmentation using xenogenic bone substitute material Bio-Oss ${ }^{\circledR}$ in combination with venous blood. A histologic and hsitomorphometric study in humans. Clin Oral Implants Res. 2000;11(3):217-229.

5. Sani E, Veltri M, Cagidiaco MC, et al. Sinus membrane elevation in combination with placement of blasted implants: a 3-year case report of sinus augmentation without grafting material. Int J Oral Maxillofac Surg. 2008;37(10):966-969.

6. Precheur HV. Bone graft materials. Dent Clin North Am. 2007;51(3):729-746.

7. Tabata Y. Biomaterial technology for tissue engineering applications. $J$ $R$ Soc Interface. 2009;6:S311-324.

8. Barone A,Varanini P, Orlando B, et al. Deep-frozen allogenic onlay bone grafts for reconstruction of atrophic maxillary alveolar ridges: a preliminary study. J OralMaxillofac Surg Philadelphia. 2009;67(6):13001306.

9. Katsuyama H, Jensen SS. Procedimentos de elevação do assoalho do seio maxilar. In Chen S, Buser D, Wismeijer D, editors. ITI Treatment Guide. Berlim; Quintessense. 2012;5:45-46.

10. Caregnato L, Ponzoni D, Matsumoto MA, et al. Levantamento do seio maxilar usando substitutos ósseos autógenos e alógenos. Relato de caso e análise histológica após sete meses. Implant News. 2010;7(7):437-480.

11. Dinato JC, Nunes LS, Smidt R. Técnicas cirúrgicas para regeneração óssea viabilizando a instalação de implantes. In: Saba-Chufji E, Pereira SAS. Periodontologia: Integração e resultados. São Paulo: Artes Médicas. 2007; cap. 14, p.183-226.

12. McGhumphy EA, Larsen PE. Implantes contemporâneos em odontologia. In: Peterson LJ, Ellis E, Hupp JR, Tucker MR. Cirurgia oral e maxilofacial contemporânea. Rio de Janeiro: Elsevier; 2005:325-363.

13. Rickert D, Slater JJ, Meijer HJ, et al. Maxillary sinus lift with solely autogenous bone compared to a combination of autogenous bone and growth factors or (solely) bone substitutes. A systematic review. Int J Oral Maxillofac Surg. 2012;41(2):160-167.

14. Pallesn L, Schou S, Aaboe M, et al. Influenece of particle size of autogenoses bone grafts on the early stages of bone regeneration: a histologic and stereologic study in rabbit calvarium. Int J Oral Maxillofac Implants. 2002;17(4):498-506.

15. Schlegel KA, Fichtner G, Schultze-Mosgau S, et al. Histologic findings in sinus augmentation with autogenous bone chips versus a bovine bone substitute. Int J Oral Maxillofac Implants. 2003;18(1):53-58.

16. Wenz B, Oesch B, Horst M. Analysis of the risk of transmitting bovine spongiform encephalopathy through bone grafts derived from bovine bone. Biomaterials. 2001;22(12):1599-1606.

17. Maximo FS, Wassal T. Análise histomorfométrica de enxerto ósseo autógeno versus xenógeno na calvária de ratos. Implant News. 2012;9(6):131-137.

18. Kaufman E. Maxillary sinus elevation surgery: an overview. J Esthet Restor Dent. 2003;15(5):272-282.

19. Guilherme AS, Zavanelli RA, Fernandes JMA, et al. Implante osseointegráveis em áreas com levantamento do seio maxilar e enxertos ósseos. RGO Porto Alegre. 2009;57(2):157-163.

20. Mattos FS, Silveira VAS, Balducci I, et al. Estudo comparativo de três técnicas histológicas para análise da reparação óssea em tíbias de rata. Clipe Odonto. 2011;3(1):2-8.

21. Tibana C, Sasaki FG, Oliveira JP, et al. Levantamento bilateral de seio maxilar utilizando biomaterial sintético associado a plasma rico em plaquetas: relato de caso clínico e análise histomorfométrica. Implant News. 2012;9(6):95-104. 
22. Bauer TC, Muschler GF. Bonegrafts materials In. Clinical Orthopedics and Related Research. 2000;21:10-27.

23. Herculiani PP, Cestari TM, Taga EM, et al. Tratamento de defeito ósseo perene em calvária de cobaia com membrana de cortical óssea bovina liofilizada associada ou não a enxerto ósseo bovino desmineralizado. Rev Brasil Implant Rio de Janeiro. 2000;6(2):7-14.

24. Tadjoedin ES, de Lange GL, Bronckers ALJJ, et al. Deproteinized cancellous bovine bone (Bio-Oss ${ }^{\circledR}$ ) as bone substitute for sinus floor elevation. J Clin Periodontol. 2003;30(3):261-270.

25. Ramírez-Fernández MP, Calvo-Guirado JL, Delgado Ruiz RA, et al. Experimental modelofbone response toxenograftsofbovineorigin (Endobon ${ }^{\circledR}$ ): a radiologicalandhistomorphometricstudy. Clin Oral Impl Res. 2010;22(7):727-734.

26. Travassos JR, Spin-Neto R, Santana IL, et al. Análise clínica, tomográfica e histológica comparativa entre BoneCeramic e Bio-Oss ${ }^{\circledR}$, utilizados como enxertos após a elevação da mucosa do seio maxilar em humanos: relato de caso clínico com desenho do tipo boca dividida, acompanhado durante oito meses. Implant News. 2013;10(6):735-742.

27. Corá GG, Faloni APS, Faeda RS, et al. Bio Oss ${ }^{\circledR}$ versus BoneCeramic para elevação bilateral de seio maxilar no mesmo paciente: avaliação histológica qualitativa após seis meses. Implant News. 2014;11(3):323328.

28. Sartori S, Silvestri M, Forni F, et al. Ten-year follow-up in a maxillary sinus augmentation using anorganic bovine bone (Bio-Oss ${ }^{\circledR}$ ). A case report with histomorphometric evaluation. Clin Oral Impl Res. 2003;14(3):369-372.

29. Maiorana C, Redemagni M, Rabagliati M, et al. Treatment of maxillary ridge resorption by sinus augmentation with iliac cancellous bone, anorganic bovine bone, and Endosseous Implants: A clinical and histologic report. Int J Oral Maxillofac Implants. 2000:15(6):873-878.

30. Ramírez-Fernández, Calvo-Guirado M, Delgado-Ruiz JL, et al. Retracted: Bone response to hydroxyapatites with open porosity of animal origin (porcine [OsteoBiolßmp3] and bovine [Endobon $®$ ]): a radiological and histomorphometric study. Clin Oral Implants Res. 2011;22(7):767-773.

31. Jang HY, Kim HC, Lee SC, et al. Choice of graft material in relation to maxillary sinus width in internal sinus floor augmentation. J Oral Maxillofac Surgery. 2010;68(8):1859-1868.
32. Raghoebar GM, Vissink A, Reintsma RHK et al. Bone grafting of the floor of the maxillary sinus for the placement of endosseous implants. Brit J Oral Maxillofac Surg. 1997;35(2):119-125.

33. Vasconcelos LW, Lima EG, Takagui RM et al. Enxerto ósseo autógeno em seio maxilar com implantes imediatos. Rev Assoc Paul Cir Dent. 1998;52(1):35-41.

34. Gutwald R, Haberstoh J, Kuschnierz J, et al. Mesenchymal stem cells and inorganic by autologous bone in adult sheep. Br J Oral Maxillofac Surg. 2010;48(4):285-290.

35. Artzi Z, Kozlovsky A, Nemcovsky CE, et al. The amount of newly formed bone in sinus grafting procedures depends on tissue depth as well a the type and residual amount of the grafted material. J Clin Periodontol. 2005;32(2):193-199.

36. Crespi R, Vinci R, Capparè $\mathrm{P}$, et al. Calvarial versus iliac crest for autologous bone graft material for a sinus lift procedure: A histomorphometric study. Int J Oral MaxillofacImplants. 2007;22(4):527-532.

37. Jensen T, Schou S, Stavropoulos A, et al. Maxillary sinus floor augmentation with Bio-Oss ${ }^{\circledR}$ or Bio-0ss ${ }^{\circledR}$ mixed with autogenous bone as graft: A systematic review. Clin Oral Implants Res. 2012;23(3):263273.

38. John HD, Wenz B. Histomorphometric analysis of natural bone mineral for maxillary sinus augmentation. Int J Oral Maxillofac Implants. 2004;19(2):199-207.

39. Hallmann M, Sennerby L, Lundgren S. A clinical and histologic evaluation of implant integration in the posterior maxilla after sinus floor augmentation with autogenous bone, bovine hydroxyapatite, or a 20:80 mixture. Int J Oral Maxillofac Implants. 2002;17(5):635-643.

40. Testori T, Wallace SS, et al. Repair of large sinus membrane perforations using stabilized collagen barrier membranes: surgical techniques with histologic and radiographic evidence of success. Int J Periodontics Restorative Dent. 2008;28(1):9-17.

41. Caubet J, Petzold C, Sáez-Torres C, et al. Sinus graft with safescraper: 5-year results. J Oral Maxillofac Surg. 2011;69(2):482-490. 